\title{
A SURVEY OF THE PINEAPPLE MEALYBUG IN PUERTO RICO AND PRELIMINARY STUDIES OF ITS CONTROL
}
' by $H . \hbar$. Plantit and $M r . R$. Smith, Associate Entomologists, Bureau of Entomology and Plant Quarantine, United States Department of Agriculture?. 3.

\section{- INTRODUCTMON}

The mealybug has reduced island income from pineapples.

While the growing of pineapples is well distributed in Puerto Rico, commercial plantings are confined chiefly to five main districts where the areas under cultivation total over 2,500 acres. These districts lie mostly in the municipalities of Bayamón, Corozal, Cidra, and Arecibo in the interior and on the north coast, and of Lajas on the southwest coast. The pineapple crop has been a chief source of agricultural income in most of these districts and has returned in previous years about $\$ 1,750,000$ annually for the island as a whole. It is generally believed that the mealybug, $\dot{P}$ seudococcus brevipès (Ckll.), has been responsible for decreasing this return and for causing the reduction or abandonment of some formerly high-producing areas.

Surrey revealed many ants associated with a high and well-distributed mealybug infestation.

From March to July, 1936, the writers made a brief survey of the occurrence of the mealybug and of the ants associated with it in four of the above-mentioned districts. Since then additional observations were continued to include the range of host plants throughout the island. Preliminary studies were also begun on some of the methods by which pineapple shoots, or "slips", used in planting could be cleaned of mealybugs. The survey revealed a well-distributed, rather high infestation of the mealybug and an

1. Now Associate Entomologist, Puerto Rico bxperiment Station of the United States Department of Agriculture.

2. The work here reported was carried on in cooperation with the Puerto Rico Experiment Station of the United States Department of Agrieulture at Mayaglez, with special funds avaflable to the Department for studies of insects in Puerto Rico.

3. The writers were assisted in the survey by A. S. Mason, formerly Associate Forticulturist, Puerto Rico Experiment Station of the United States Department of Agrieultire. 
active association of $\mathbf{a}$ large number of species of ants; the control studies indicated that by subjecting the slips to vapor heat for varying periods, an economical and effective method of cleaning planting stock of mealybugs might be evolved.

Because of the importance of the information obtained, it seems desirable at this time to summarize in the present paper the, results of the survey and of other observations and to record the work done on control.

\section{Survey of Infestation}

Pineapple plants were examined in eross rows as well as on the edges of the fields.

The Bayamón-Corozal district can be considered the center of the pineapple industry of the island. In April, six well-scattered fields of young plants of the Red Spanish variety, representative of the district as a whole, were examined in the municipalities of Toa Baja, Bayamón, and Corozal. Practically all the fields examined were planted in July 1935, and the majority were on sandy clay in more or less hilly country, such as that shown in figure 1 . .

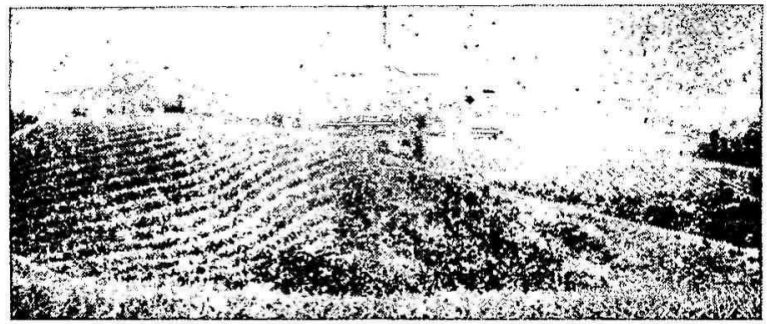

Fig. 1. View of part of a large pineapple plantation near Corozal, showing t.ype of land devoted to pineapples in most of this district.

In making inspections for mealybugs and ant attendants the method was to select and examine plants spaced approximately 10 steps apart in a typical row running across the fields; in addition the end plant of every other row on the edge of the same fields was also examined. Wherever there was any difference in 
surrounding conditions, the plants on the edge adjacent to a turnrow or pasture were selected with the idea of revealing the possible influence of other hosts of the mealybug. In examining the plants, the leaves were bent down and as thorough a search as possible made for the presence of the mealybug and attending ants without actually pulling up the plant or tearing it apart. ,

\section{Average infestation of 86.3 percent in Red Spanish variety was well distributed.}

On the six plantations visited in the Bayamón-Corozal district there was found an infestation of 86.3 percent of a total of 204 plants examined. On two plantations all the plants examined were found infested. The lowest infestation for any plantation was $\mathbf{6 6 . 7}$ percent.

The results for this district showed little difference in percentage of mealybug infestation between the plants in the cross rows and those on the edges of the fields; of these 9-month-old plants, 89.6 percent in the cross rows were infested, as compared with 82.7 percent on the edges. The infestation in the cross rows varied among the plantations from 71.4 to 100 percent, while that on the edges varied from 61.1 to 100 percent. These infestations are relatively high and indicate that infested plants are well distributed and not so concentrated on the edges as has been reported occurring during the early stages of infestation in Hawaiin pineapple fields $(6,2,3)$.

The intensity of mealybug infestation was found to be high in many cases. In one field the mealybugs were feeding abundantly on the roots of some plants, while in other fields they were found near the tip of the center leaves. Although no comparative counts were made, the number of mealybugs per plant in most instances seemed to be greater, but perhaps not significantly so, on the edges of the fields than inside.

The elevation on the fields examined in this district varied approximately from 60 to 1,500 feet above sea level, but neither this nor soil type appeared to have any influence on infestation or its intensity.

Intensity of mealybug infestation increased with age of plants.

Practically the same conditions as mentioned above were found in April in two typical fields of the Red Spanish variety on a plan- 
tation neảr Arecibo. These fields were planted in July 1935 in sandy, reddish-brown clay soil of flat topography and medium elevation. Among the 40 plants examined in cross rows, 82.5 percent were infested, as were $8 \dot{5} .7$ percent of 35 plants on the edges; total infestation, both across and on the edges, 84.0 percent.

At the same time an examination was made in another field at Arecibo which was planted in July 1934, about a year earlier than the fields just mentioned. The plants in this older field were large and the fruits approaching maturity. Among 25 plants examined in a row across this field 76.0 percent were found infested by the mealybug, while of 25 plants on the edge of the same field 92.0 percent were found infested. The total infestation was 84.0 percent, the same as in the young fields just mentioned.

The intensity of the infestation in the young fields at Arecibo seemed to be about the same as in those examined in the Bayamón-Corozal district, with very little difference between cross rows and edges. However, as might be expected, the intensity of infestation in the older field at Arecibo was much higher; a number of plants were found supporting much larger colonies of mealybugs, and many more such plants were located on the edge than inside of the field.

Infestation in "Cabezona" variety was high.

In March, a field of the Cabezona variety was examined on a plantation near Lajas. This field, of slight elevation, contained plants of various ages from recent replants to those in bearing, or approximately 2 years of age. The soil was a rather exhausted, red clay loam. Here every other plant was examined in alternate rows until 4 plants had been. inspected in each of 5 rows, a total of 20 plants, in each of the 4 corners and the center of the field. All the plants thus examined in the center and in two diagonally opposite corners were infested by the pineapple mealybug, as were 90 and 95 percent, respectively, of the plants in the other two corners. Considering all, the plants in the comers as outside plants, there were 96.3 percent of these infested as against 100 percent in the center of the field; again little difference. The average total infestation was 97. percent. The majority of the plants, especially the older ones, were so heavily atţacked by the mealybug that 
they had a decidedly wilted appearance. While adverse growing conditions may have been partly the cause of this, there was a strong probability that the mealybug was mainly responsible.

At the same time, a small patch of pineapples grown for home use was examined on another property a little farther south of. Lajas. While a number of varieties and ages were represented, most of the plants were of the Pan de azúcar variety and about 8 months old. Of 10 plants examined at random in the center of 10 rows, 70.0 percent were found infested by the mealybug, while of 20 on the 2 ends of the field 75.0 percent were infested; total infestation 73.3 percent. In the absence of actual counts, the intensity of infestation appeared to be at least as high as in most young fields examined in other parts of the island.

\section{Character of Injury and Importance}

Mealybug-infested plants were stunted, chlorotic, and wilted and harbored many ants.

The young plants found injured in the Bayamón-Corozal and Arecibo districts were stunted and had narrower leaves than those

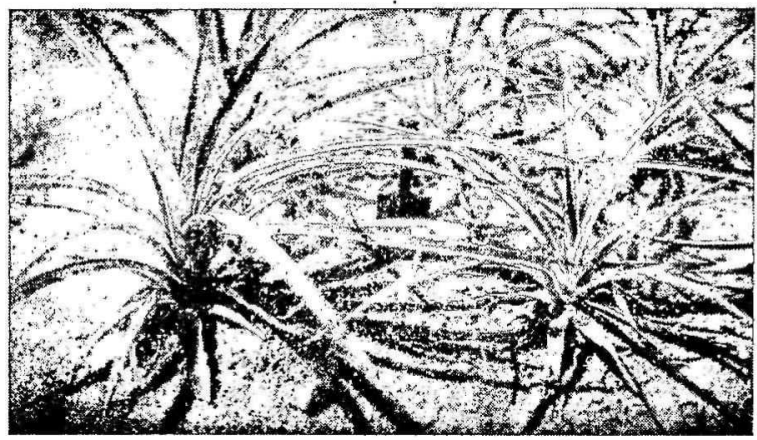

Fyg. 2. Two pineapple plants of the Red Spanish variety photographed at 9 months of age; the one on the left is uninfested and that on the right heavily infested with the pineapple mealybug attended by ants. Note the stunted condition and narrow leaves of the infested plant, characteristic of injury caused by this association of pests. 
usually present on normal plants of the same age. One such plant is illustrated at the right in figure 2. The leaves had an unhealthy, yellow-green color and here and there irregular, slightly chlorotic blotches. Wherever infested plants were found, considerable soil was generally seen piled up in the axils of.the leaves by attending ants, as shown in figure 3 . Some growers said that this factor alone

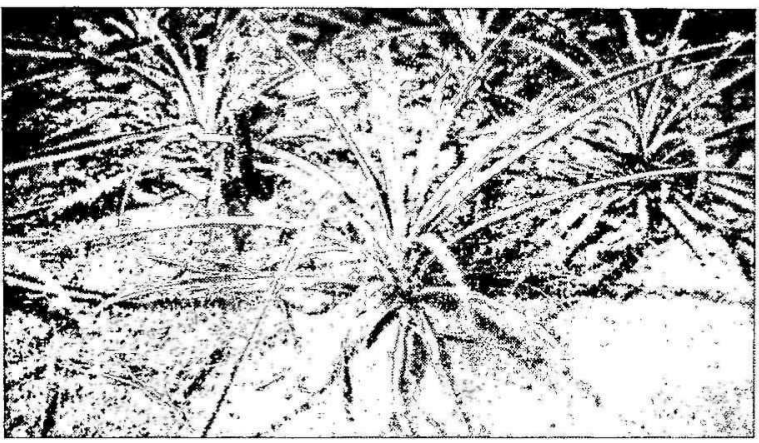

Fig. 3. Close-up of a 9-month-old Red Spanish pineapple plant infested with the pineapple mealybug, showing nest made at base and soil placed over mealybugs in axils of lower leaves by fire ants.

is sufficient to interfere seriously with normal growth, as -sometimes occurs when soil is lodged in the leaf axils by wind or careless cultivation.

As the plants grow older, the above injury becomes intensified, the leaves grow still more pronouncedly chlorotic and narrow, and in general the plant assumes a sickly, dusty appearance, suggestive of the symptoms of pineapple wilt as described by writers on this disease in Hawaii $(6,4)$. The infested old plants of the Cabezona variety examined in the Lajas district distinctly showed this type of injury. While not actually observed by the writers, they were informed that a small experimental planting of the Smooth Cayenne variety made in Puerto Rico some years ago was particularly affected by mealybug infestation and that the plants soon became wilted and died. 
Fruits are attacked and their size, quality, and yield seriously reduced.

The mealybug at times infests the flowers, stalk, and fruit, so that some mature fruits will be gnarly and have fibrous flesh with mealybugs sealed in the eyes. A. S. Mason, who has made observations on the pineapple mealybug for a number of years as an agricultural economist, stated that severe infestations have caused production to fall from 175 to 225 crates per acre from a former normal production of 275 to 350 crates per acre, or an average loss of about 36 percent. In the case of salable fruits, he found those from heavily infested fields to average 36 per crate, while such fruits from fields that were commercially free from mealybug infestation were larger and averaged 28.5 per crater The writers were told by experienced growers that the intensity of mealybug infestation found in the young plants examined in the present survey was sufficient to cause losses approximating the above.

According to many growers, both the extent and the intensity of mealybug infestation have been increasing gradually during the last 6 or 8 years and are now threatening the profitable growing of pineapples in many places in Puerto Rico. It was stated by some that the mealybug was largely responsible for the so-called failure of new land after 3 or 4 years. Ordinary methods of plantation management have yielded unsatisfactory results. The use of clean seed and the spraying of infested fields, as practiced at the present time, are also said to have produced generally poor and costly control. From the present survey the problem of ant control appears to be involved as much as, or more than, that of the mealybug, since ants are an important factor in the dissemination of mealybugs from many host plants to and throughout a field, as well as in interfering with normal pineapple growth and production through lodging soil in the axils of the leaves.

\section{Host Plants of the Pineapple Mealybng}

\section{Pineapple mealybug occurred most abundantly in commercial plantings.}

The pineapple mealybug doubtlessly occurs on pineapples in every section of the island where this plant is grown, regardless of 
variety or whether the plantings are for commercial or for home use. Mealybugs have, however, been found most abundantly' in commercial plantings, both with regard to the number of pineapple plants infested and the number of individuals per plant. Judging from examinations made in fields that have been plowed up and in refuse that has been removed therefrom, old pineapple stumps and the chance shoots growing from.them will serve as hosts of the mealybug for many months after being uprooted. A pile of such disćarded stumps, still heavily infested with mealybugs, is shown in figure 4. While making the above survey and in con-

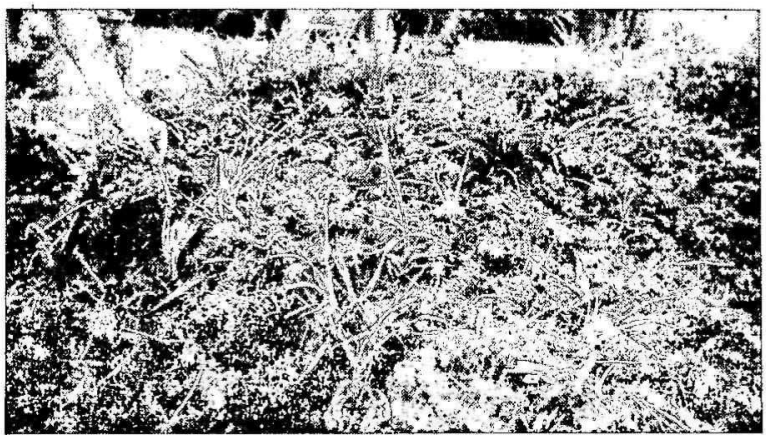

Fig. 4. Discarded pineapple stumps still heavily infested with mealybugs 6 months after having been plowed up and piled on edge of an old pineapple field. Such crop remnants furnish a dangerous source of infestation to new plantings.

tinuing observations elsewhere since then, the writers found 18 additional species of plants that were infested by this insect. A list of these plants is given in table 1 . 


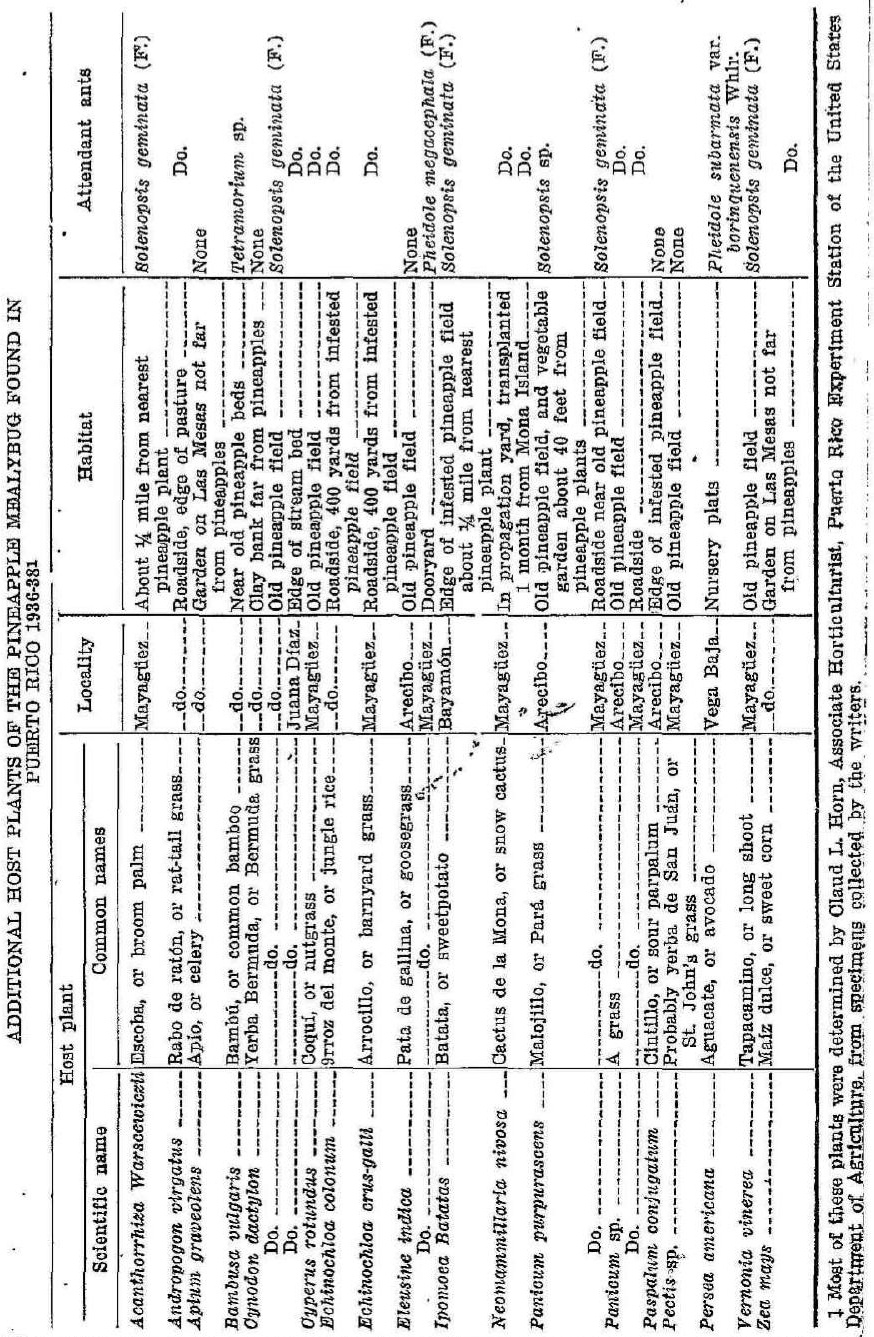




\section{Grasses growing in many habitats harbored the pineapple mealybug.}

Pará grass, Panicum purpurascens, seemed to be one of the grasses preferred by the mealybug around Mayagiez and Arecibo. On this grass, which is common in the island, were found many pineapple mealybugs, and these were invariably attended by strong colonies of the fire ant, Solenopsis geminata (F.). In figure 5 is shown a group of several kinds of grasses growing some distance

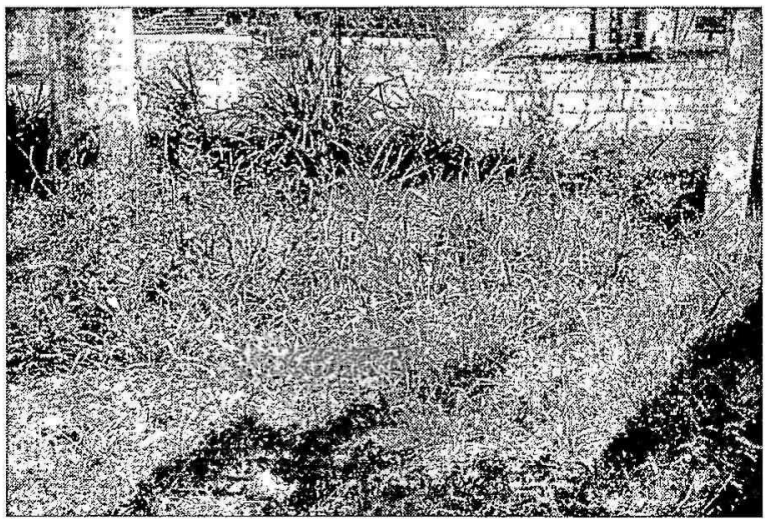

Fig. 5. Group of several kinds of grasses harboring the pineapple mealybug on edge of a field several hundred yards from where pineapples had been grown some months previously. In such habitats as this, ants are able to become well colonized and, by actively fostering the mealybug, later transfer it to the newly planted field.

from an old pineapple field. Most of the plants in this particular group were found infested with the mealybug.

Twenty-five host plants have been recorded for the pineapple mealybug in Puerto Rico.

Besides pineapple and nutgrass, Wolcott (11) lists the following plants as hosts of this insect: Saccharum officinarum, "young 
bud coming out from roots of sugarcane"; Ifusa sapientum, "banana rootlets"; ficus laevigata, "aerial roots of jaguey, attended by hormiguilla", Mfyrmelachista ambigua subsp. ramuloruin Whlr.; Punica Granatum, "pomegranate"; and Tamarindus indica, "tamarind". Fife (5) recorded the pineapple mealybug on cultivated cotton. So far as the writers can find, this makes a total of 25 host plants that have been recorded for the pineapple mealybug in Puerto Rico.

The data here presented show that the pineapple mealybug has many other host plants than pineapple, that certain grasses and weeds growing in a pineapple field or near the edges of the field can harbor the mealybug and be reservoirs of infestation, and that even plants far removed from a pineapple field act as hosts for this pest.

Ant Associates

Of the 16 species of ants found associated with the pineapple mealybug, 3 were seen carrying this insect.

Examinations of pineapple fields in the localities already referred to revealed 16 species of ants to be. definitely associated with the pineapple mealybug in Puerto Rico. Collections of ants were made from the pineapple plants that were infested with mealybugs, and the different species of ants found are arranged in table 2 according to the percentage of times each was noted.

If 13.6 percent of the instances in which ants were seen in the survey there were more than one species of ants found attending mealybugs on the same pineapple plant. In only one field were ants found on less than 50 percent of the mealybug-infested plants; in most cases the percentage was considerably higher, the highest being 92.9 percent. In rows running across the fields ants were seen attending mealybugs on 63.2 percent of the infested plants, in the rows on the edges of the same fields 81 percent. These figures.

- indicate a definite association between the ants and the mealybug; they also indicate a definite relation of the surrounding vegetation to the ant distribution within the field itself, since this vegetation was without cultivation and much of it consisted of hosts of the mealybug or other honeydew producing insects. Three species of 
ants were often actually seen carrying healthy-looking mealybugs in their mouths; these ants were Solenopsis gominata, Brachymyrmex heeri var: obscurior, and Prenolepis (Nylanderia) sp. probably fulva.

\section{TABLE 2}

SPFCIES OF ANTS DEFINITELY ASSOCIATED WITH THE PINEAPPLE MEALYBUG IN PUERTO RICO, WITE PERCENTAGE OF OCCURRENCE WITH MEALYBUGS ON PINEAPPLE PLANTS1

\begin{tabular}{|c|c|c|c|}
\hline \multirow[t]{2}{*}{ Rank } & Species & \multicolumn{2}{|c|}{$\begin{array}{c}\text { Occurrence } \\
\text { with mealy- } \\
\text { bugs on } \\
\text { pinerpple } \\
\text { plants }\end{array}$} \\
\hline & . & & Percent \\
\hline 1 & Solenopsis gcminata (F.) & & 43.3 \\
\hline 2 & Brachymyrmex hceri var. obscurior Forel. & & . $\quad 36.2$ \\
\hline 3 & Honomorium floricola (Jerd.) & & 11.6 \\
\hline 4 & Solenopsis sp. & & 6.5 \\
\hline 5 & Wasmannia auropunctata (Rog.) & & 2.7 \\
\hline 6 & Paratrechina longicornis (Latr.) - & " & \\
\hline 7 & Paratrechina (Nylanderia) fulva (Mayr) & & 2.4 \\
\hline 8 & Tapinoma melanocophalum (F.) & & 2.0 \\
\hline 9 & Grematogaster steinheiti Forel _._. & & 1.7 \\
\hline 10 & Phoidolc subarmata var. borinquenensis Whir. . & & 1.4 \\
\hline *11 & Cardiocondyla emeryi Forel & & 1.0 \\
\hline 12 & Brachymyrmex heeri Forel & & .7 \\
\hline 13 & Irononoriun carbonarium subsp. ebeninum Forel... & & .7 \\
\hline 14 & Paratrechina (Nylanderia) sp. & & .7 \\
\hline 15 & Phcidole megacephata (F'.) & $\mathbf{2}$ & .0 \\
\hline 16 & Tetramorium sp. & 3 & .0 \\
\hline
\end{tabular}

1 Many of these species have previously been reported by the junior author (10). 2 Folund associated with the pineapple mealybug on goosegrass.

3 Found attending the pineapple mealybug on bamboo.

In both the Bayamón-Corozal and Arecibo pineapple-growing districts the fire ant, Solenopsis geminata, and the ant, Brachymyrmex heeri var. obscurior, were the only species commonly found attending the mealybug, whereas in the drier, Lajas area, in the southwest corner of the island, 13 species were found, the ant, Monomorium floricola, being first in frequency and the fire ant second.

Pheidole megacephala, the most common ant associated with the 
pineapple mealybug in Hawaii (2), was also found attending the pineapple mealybug in Puerto Rico, not on pineapple, however, but on a single plant of goosegrass that was growing in a dooryard in Mayagüez. Although this ant is not native to Puerto Rico, it is apparently well established in several towns, but has not yet been recorded in the rural areas or in the pineapple-growing sections of the island.

The crazy ant, Paratrechina longicornis, although of little importance as compared with other species, is a honeydew-loving species and has been definitely found associated with this pineapple pest. Tapinoma melanocephalum, a common ant and one that will attend honeydew-excreting insects when the opportunity offers, has not yet been found in sufficient abundance in the pineapple fields to be a great factor in the association complex.

\section{The fire ant was of greatest economic importance.}

The first four species of ants given in table 2 appeared at the time of making the survey tọ be of sufficient abundance to warrant serious consideration as ants that primarily attend the pineapple mealybug. Two of these, the fire ant, Solenopsis geminata, and Brachymyrmex heeri var. obscurior, were widely enough distributed in the pineapple fields and occurred in large enough numbers to be considered of economic significance. However, the fire ant is by far the most important species associated with the mealybug in Puerto Rico. It occurs in large numbers in every field that was examined; its colonies are larger than those of any of the other species found associated with the pineapple mealybug; and, being of an omnivorous nature, this ant is not entirely dependent on honeydew as some of the other species are. The fire ant thrives in open, sunny habitats such as those offered by pineapple fields. It is aggressive and vicious, and its nests are of the compound type, that is, made up of many scattered but component parts. A typical nest made by this ant in grass land near a pineapple field is shown in figure 6 . 


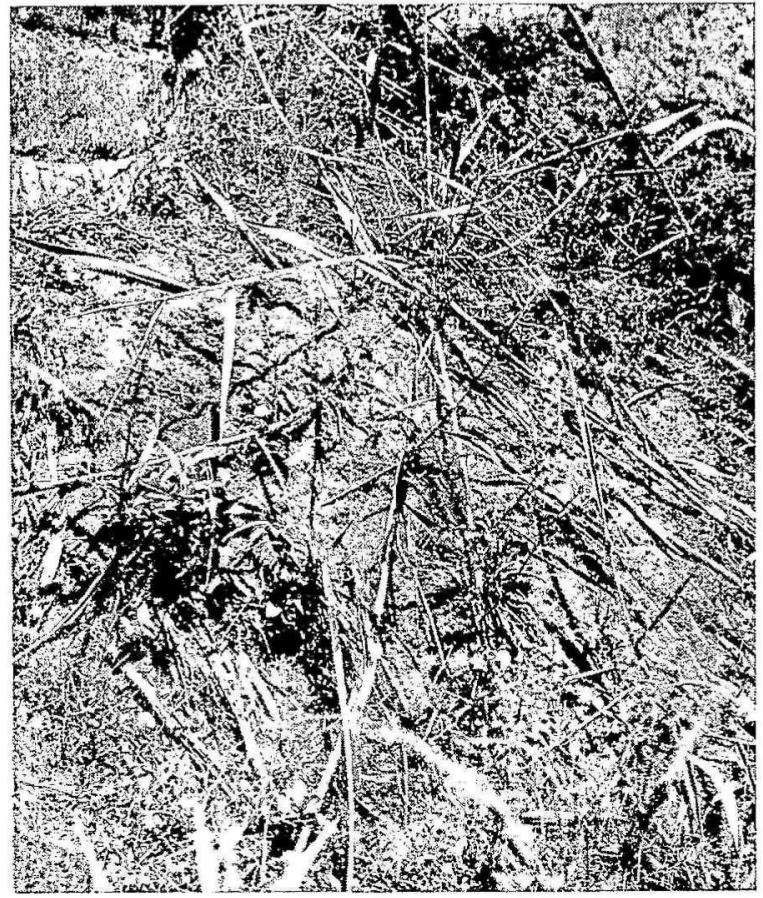

Fig. 6. Typical nest. of the fire ant, Solenopsis geminnata (F.), in grass land near where plneapples had previously been grown. Note the loose soil with numerous openings into the nest. Ants from this nest were found attending the pineapple mealybug and other scale insects on several grasses in this area. The honeyclew excreted by all these insects enables this and other important ants to maintain their colonies at the hlghest point of activity and later to disseminate the mealybug throughout nearby pineapple plantings.

It is therefore the opinion of the writers that the main fight against ants as disseminators of mealybugs in Puerto Rico will 


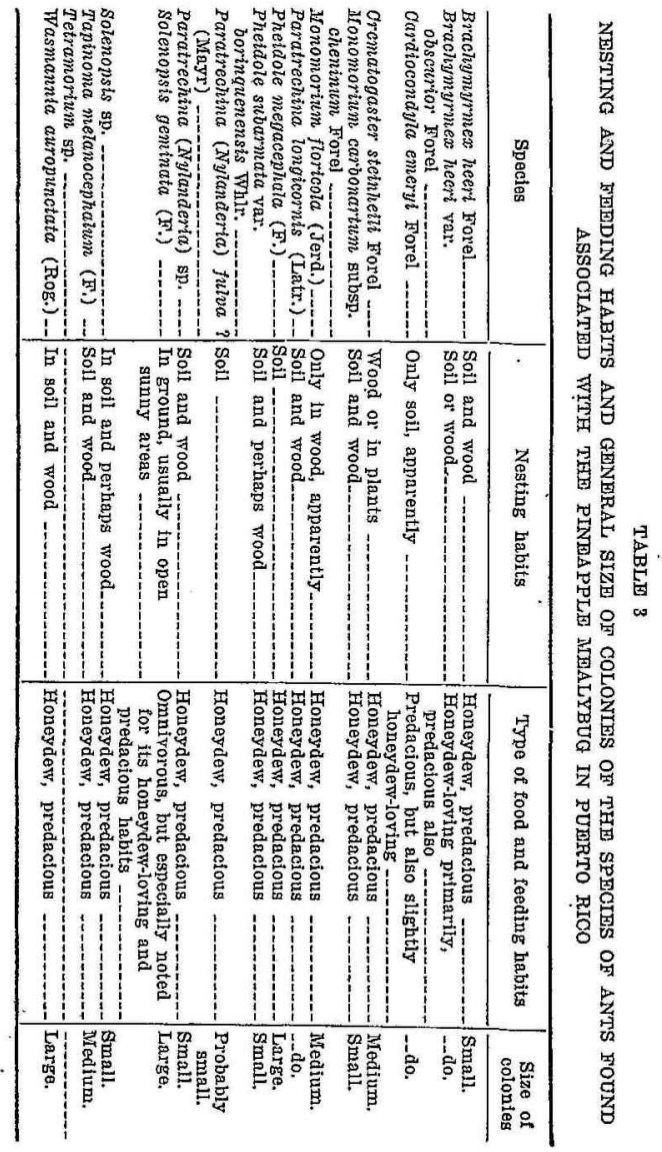


have to be directed largely. against the fire ant. Another species, Brachymyrmex obscurior, a small ant that feeds principally on honeydew, should also be included because of its abundance. Fortunately this ant is not aggressive or omnivorous; its colonies are small, consisting usually of only a few hundred individuals, and not widely scattered in the soil.

Honeydew is one of the main foods of the ant associates of the pineapple mealybug.

Table 3 is inserted here to elucidate facts bearing on the general habits and biology of the ants found attending the pineapple mealybug in Puerto Rico. A study of the general nesting habits, type of food, and size of the colonies of the species given in this table will furnish much information regarding the potentialities of these insects as fosterers and disseminators of the mealybug.

While all the ants listed in the foregoing table have predacious habits, the principal food of nearly all of them is honeydew. Many are noted for their habit of propagating and protecting the source of this food. In this class are the fire ant and the other species discussed in the preceding paragraphs.

Plants that harbor honeydew-excreting insects provide food for ants that disseminate the pineapple mealybug.

If plants that harbor other honeydew-excreting insects than Pseudococcus brevipes are allowed to grow in a pineapple field or on the edges, these plants will furnish a source of abundant honeydew food to the ants that are oxdinarily associated with the pineapple mealybug and thus tend to make these ants more difficult to control or eradicate. Two good illustrations of how this might react against good plantation management were noted in the survey. In a field not far removed from an old pineapple planting, a soft scale, Aclerda sacchari Teague, was found colonized on the stems and roots of two grasses. An abundance of fire ants had not only built earthen coverings over some of the scales on the stems but were also busily attending the scales around the roots. On another plantation, fire ants from strong colonies were found 
attending mealybugs of the genus Trionymus on the roots of goosegrass, Eleusine indica, and stems of malojilla, Eriochloa punctata. Obviousty, plants harboring such honeydew-producing insects will permit colonies of this ant and others that attend the pineapple mealybug to maintain themselves at full strength and thus to thrive on and disseminate the mealybug in nearby new plantings.

\section{Natural Enemies}

\section{Three species of small larvae may be possible predators.}

While making the examinations detailed earlier in this report, a number of flesh-colored caterpillars about one-fourth inch long were frequently found in the waxy secretion around large groups of old mealybugs in the axils of pineapple leaves. Many of the mealybugs were dead, but, although the caterpillars may have been acting as scavengers feeding on the wax and other accumulated organic matter, it is possible that they may have been preying on the mealybugs. Some moths reared from these caterpillars were determined in the Bureau of Entomology and Plant Quarantine by August Busck as a species of Tinea and others by Carl Feinrich as a species of the pyralid genus Gonopasclia, probably protomis Dyar.

A few small, light-pink maggots were also found associated with the pineapple mealybug in the same situations as described above. While not actually seen attacking the mealybugs, it is thought that they were responsible for the death of at least a small percenfage. The flies reared from these maggots were determined by C. T. Greene of the Bureau of Entomology and Plant Quarantine as a species of the family Cecidomyiidae belonging to a genus near to Neolasioptera. These three species of insects appear to be the only ones that have been reared from and that might be considered as natural enemies of the pineapple mealybug occurring at the time of this writing in Puerto Rico.

\section{One recently introduced parasite has become established.}

Through the cooperation of the Bureau of Entomology and Plant Quarantine and the Puerto Rico Experiment Station of the United States Department of Agriculture, two hymenopterous parasites, Anagyrus cocciclivorus Dozier and Ilambletonia pseudococcina 
Compere, were introduced from Brazil and Hawaii curing 1936 and 1937. By extensive rearings and liberations, K. A. Bartlett, who has had charge of the colonization of these parasites in Puerto Rico, succeeded in establishing Hambletonia in pineapple fields near Lajas and Arecibo, but has been unable as yet to recover Anagyrus at any of the places where it was liberated (1).

Until these or other introduced natural enemies are able to bring about adequate control, it would seem advisable to investigate the other means by which pineapple mealybug injury might be reduced.

\section{Control Studies}

With so many ants potentially able to disseminate the pineapple mealybug throughout new plantings and so few natural enemies to reduce its numbers, one of the most important steps in the control of this pest is the use of clean planting material. In the control studies that were undertaken emphasis was therefore placed on some of the methods by which the seed might be readily cleaned of mealybugs. At the same time data were collected on the effect of ants on the mealybug infestation in recently planted pineapples.

Methods of freeing planting slips of mealybugs were tested. .

Several lots of approximately 100 commercial planting slips each were given separate treatments in an orientation experiment designed to indicate the effects of these treatments on both the mealybugs and the slips. The slips, all of the Cabezona variety, were heavily infested with Pseudococcus brevipes. All lots were homogenized by dealing the slips out in successive rotation into piles from the container in which received.

Because of the success obtained in the control of similar insects by submersion in water (9), two of the experimental treatments were of this nature. In one such treatment the slips were held submerged for a period of 72 hours and in another for 96 hours. After the slips had been packed in 50-gallon iron drums and held down with coarse wire cloth, the drums were filled with tap water to cover the slips completely. The slips were thus held without change of water to the end of above respective periods. 
Another treatment involved the use of vapor heat as employed in Hawaii by McBride (8). In this treatment the slips were subjected to moisture-laden air heated to a temperature of about $46^{\circ} \mathrm{C}$., approximately $115^{\circ} \mathrm{F}$., for a period of 6 hours in a vapor-heat room that had been used in the sterilization of fruit (7).

The relative humidity of the air circulated in the room was maintained with slight variation at about the saturation point. A thermometer, the bulb of which was stuck into a pineapple slip near the center of the sack containing them, was used to record the inside temperature of the slips. A sling psychrometer was used to measure the humidity of the air in the room. These instruments were read by entering the room every half hour throughout most of the treatment.

It took $51 / 2$ hours to raise the inside temperature of the pineapple slips to $46.5^{\circ} \mathrm{C}$. The fact that the room had to be entered to read the thermometers, which each time caused the temperature to drop about 2 degrees, undoubtedly operated to prolong this approach period. During the subsequent 6 hours of treatment the inside temperature ranged between $46.5^{\circ} \mathrm{C}$. and $47^{\circ} \mathrm{C}$. most of the time.

\section{After treatment, slips were planted in sterilized soil and guarded from ants.}

Immediately or the next day following treatment, each of the three foregoing lots of treated slips and a fourth lot containing untreated slips free from ants were planted in groups of three or four slips each in 10-inch pots, the upper 2 inches of which were filled with soil from a pineapple field. As each slip was planted, a thin section of the base was eut off with a sharp lnnife to reach . fresh tissue and a few of the lowest leaves were stripped off to expose about one-fourth to one-half inch of root zone. In this operation some mealybugs were dislodged and lost, but probably not to the extent as would occur in commercial practice. In order to avoid any contaminating infestation, the soil used for planting had been previously sterilized in the pots by exposure to steam-heated air in the vapor heat room to kill any mealybugs that may have been present. The pots of sterilized soil were then held on antguarded tables until used. 
After being planted, each of the four lots of slips was kept separate from the other on ant-guarded tables in order to prevent any natural spread of mealybugs from one lot to another, or possible reinfestation by means of ants. When the plants needed moisture they were sprinkled with tap water. The plants were held under these conditions for about 6 weeks to allow any deleterious effects of the treatment on the plants to become evident. This also allowed time for any young mealybugs remaining alive after treatment to develop so they could be easily counted, but not sufficient time for older living stages to reproduce and interfere with the accuracy of the final counts.

Beginning 43 days after treatment, the slips in all lots were dissected. The number of female mealybugs found still alive on the living slips were recorded together with the number of plants that had died to date of examination. These data and the percentage of living slips infested, the percentage of slips dead, and the average number of living female mealybugs found per infested slip are given in table 4 . In the last column of this table is also given the percentage of mealybugs killed by each treatment. This was calculated according to the usual formula after bringing the living population in each lot of slips to the same level.

It will be noted in table 4 that the highest kill of mealybugs, 99.13 percent, the lowest infestation, 4.4 percent, and the lowest average number of living mealybugs per infested slip, 1.0, were obtained by keeping the slips submerged in water for 96 hours; but this treatment caused over half of the slips to die. Reducing the time in water to $7 \dot{2}$ hours resulted in 92.04 percent kill of the insects and 8 percent infestation among the slips, but the infested slips still contained an average of five living mealybugs each, and 15.5 percent of the slips later died.

It will also be noted in table 4 that practically the same percentage of mealybugs, 97.93 percent, was killed on the slips treated with vapor-heat at $46^{\circ} \mathrm{C}$. for 6 hours, as on the slips that were lsept submerged in water for 96 hours. Moreover, aside from a little scalding noted on the tip and edges of some of the outside leaves on about one-fifth of the plants, none of the slips were adversely affected by the treatment. This slight injury was still 


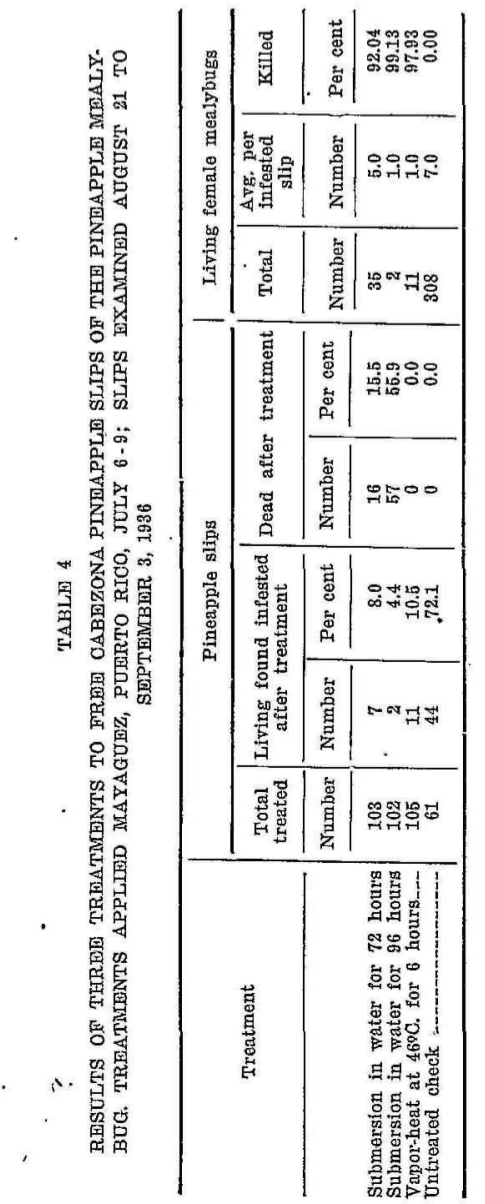


noticeable at the end of a month, but in the meantime it had been largely outgrown, ás the plants made good growth and, when compared with the untreated plants, seemed to have been stimulated somewhat by the vapor-heat treatment. Similar stimulation was reported by McBride (8).

As shown in the last line in table 4, 72.1 percent of the slips in the untreated lot were found infested, the average infestation was seven mealybugs per slip, and no slips died during the interval between planting and examination.

\section{Presence of ants increased percentage of mealybug infestation.}

In discussing the foregoing treatments it was mentioned that, in order to eliminate the factor of unnatural spread of mealybugs, ants were prevented from having access to any of the treated or untreated lots of slips. Opportunity was taken of this arrangement to obtain data on how much the ants might have increased the percentage of mealybug infestation had they not been kept from reaching the plants.

For this purpose an additional lot of slips that had been homogenized with the above untreated lot was set out in pots on another table from which the ants were not excluded. There were thus provided for observation two sets of pineapple plants, both originally bearing the same percentage of mealybug infestation, ants being kept from one set but not from the other. The results of the examination of the unguarded slips, made about $11 / 2$ months after planting, are compared in table 5 with the infestation found after the same interval on the slips that had been kept free from ants.

As shown in table 5, 72.1 percent of the slips that were guarded from ants were found infested with an average of 7.0 mealybugs each, while 83.1 percent of the unguarded slips held an average of 5.9 mealybugs each. The difference in the pereentage of slips infested in the two lots was found to be statistically significant.

When the above slips were examined, several colonies of the ant species, Tapinoma melanocephatum, were found established in some of the infested plants in the unguarded lot, and a few individual woxkers of Ifonomorium floricola were also seen attending. 


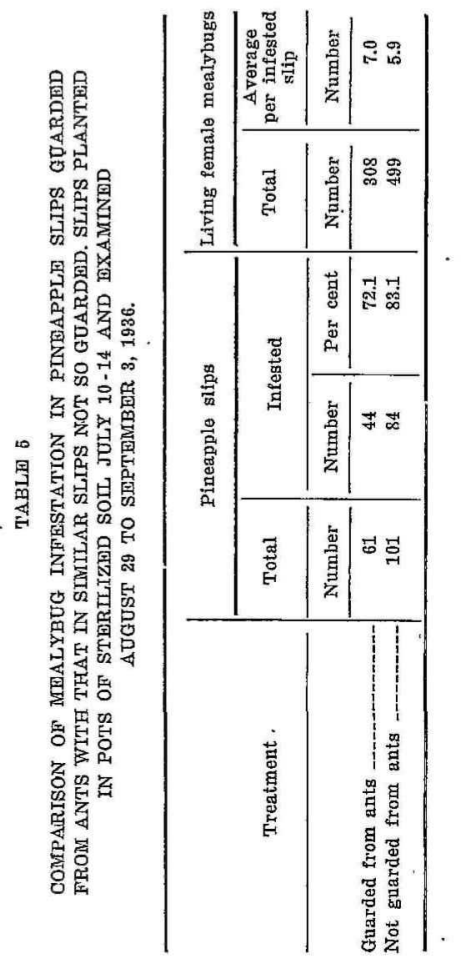


the mealybugs on some of these plants. It is evident that these ants, and possibly others not seen at the time of examination, increased the dissemination of the mealybugs throughout the unguarded slips and thus caused a higher percentage of infestation in them than otherwise would have occurred. In Hawaii it is generally considered that mealybugs will eventually disappear from pineapple plants where ants are not present to attend them $(6,2)$. The significantly lower infestation in the slips from which the ants were excluded indicates that control of ants might be helpful in preventing rapid dissemination of the mealybug in pineapple fields.

\section{Suggestions for Control}

It was evident during the foregoing work that much could be done towards the control of the pineapple mealybug by correcting faulty cultural practices, or by substituting in their place other easily adapted practices that tend to make conditions unfavorable for this pest. An effective system of plantation management necessarily takes into account the presence of host plants other than pineapple and the habits of attendant ants in carrying the mealybug from infested plants to the pineapples. Obviously, clean cultivation in and around pineapple fields will tend to reduce this spread.

Since most of the other hosts of the mealybug are grasses and colonies of attendant ants have a better opportunity for development in uncultivated land; it would be well to avoid planting pineapples on land that has lain in sod for some time or has been without previous frequent cultivation to kill out mealybug host plants and destroy ant colonies.

In preparing fields that have already been in pineapples, much early infestation in the new field can be prevented if all mealybug host plants are destroyed well in advance of replanting. Since old pineapple stumps and plants are the chief source of this early infestation, it would be well to remove and destroy such crop refuse immediately after the last crop has been harvested and not allow it to remain on or near any land that is to be used, even in the near future, for pineapples. The fertilizing value of these old 
stumps is more than counterbalanced by the fact that for a long - time they will serve to keep ant colonies active and to be a source from which mealybug infestation will spread to the succeeding erop.

After the land has thus been cleaned of pineapple plants and plowed or disked to rid it of other vegetation, and then allowed to settle for a few days, the ant colonies can then be easily located and treated with some soil fumigant to destroy as many ants as possible. Such treatment was carried out with good results in a small area by one large plantation manager, who reported that it could be made practicable on a large scale.

Rather than allow the field to remain fallow and go back to weeds and grasses after this treatment, the planting of a soil-improving crop, such as a legume, that does not harbor the mealybug of other honeydew-excreting insects, or at least is only partially susceptible to them, will tend to keep the land free of both ants and mealybugs until it is ready to plant. So far, the Crotalarias, already widely used in some districts, have proved valuable in this respect, and there may be other plants that will eventually be found to serve the same purpose. To insure best results, however, such crops must be seeded heavily so as to make a dense, shady stand and thus prevent the growth of grasses and weeds, or possible escaped pineapple plants, that harbor the mealybug. This will also tend to keep out such light-and-heat-loving species as the fire ant.

The use of clean seed, or planting slips, is of primary importance in keeping down early mealybug infestation in the new crop. The control experiments with seed treatments here reported have indicated results that warrant further investigation.

\section{Sum maxy}

A field survey of conditions in four main pineapple-growing districts of Puerto Rico revealed a mealybug infestation of 87.1 percent among pineapple plants ranging from 9 months to about 2 years of age. The infestation in individual fields varied from 66.7 to 100 percent of the plants examined, and about as many. 
plants were found infested with the mealybug on the inside of the fields as along the edges.

All parts of the pineapple plant were seen infested, roots, leaves, and fruits, as well as the stem.

Wherever heavily infested plants were found they were usually stunted, chlorotic, and often wilted, and the fruits were much reduced in size. Under conditions of severe infestation the normal yield has been estimated to be reduced by 36 percent.

Including the pineapple, 25 species of host plants of the mealybug have been recorded in Puerto Rico. Evidence obtained showed that the mealybug was widely distributed in the parts of the island where examinations were made, and that certain grasses and weeds in a pineapple field or near the edges can harbor the mealybug and act as reservoirs from which the pineapples will later be infested.

The pineapple mealybug was seldom found unattended by ants. Sixteen species of ants were found associated with this insect, all but two of these being observed attending the mealybug on pineapple plants. The fire ant, the most important species, was found in this association on over 43 percent of the infested plants on which ants were present.

Three species of ants were frequently seen carrying young mealybugs about in the fields.

The greater frequency with which ants were found attending mealybugs on pineapple plants on the edges of the fields as compared with that on the inside, indicated a definite relation of the surrounding vegetation to the ant distribution within the field itself.

That ants do spread the mealybug from infested to uninfested plants was shown experimentally.

The larvae of two small moths, one a tineid and the other a pyralid, and the larvae of a small cecidomyiid fly, all found living in large groups of mealybugs, were thought to be predators of this pest. Two hymenopterous parasites have been recently introduced, but only one has as yet become established in pineapple fields of the island. 
- In experiments with methods to clean planting stock of mealybugs, submersion of pineapple slips in water for 96 hours under the conditions described resulted in a 99.13 percent kill of the mealybugs but also killed over half the plants. Submersion for 72 hours produced 92.04 percent control but so injured 15.5 percent of the plants that they later died, and among those that survived an average of five living mealybugs were found on each infested slip.

Treating the slips in a closed room with moisture-saturated air at $46^{\circ} \mathrm{C}$., about $115^{\circ} \mathrm{F}$., for 6 hours seemed to produce the most satisfactory results. 97.93 percent of the mealybug were killed by this treatment, and although 10.5 percent of the slips still contained living mealybugs, the number averaged only one mealybug per slip. None of the planting stock was lost, and instead of injuxing the slips this treatment seemed to stimulate their later growth.

The avoidance of sod land for new fields; the removal of mealybug host plants, especially old pineapple stumps, and cover-cropping before replanting old fields; the destruction, of ant colonies; the use of mealybug-free seed; and clean subsequent cultivation are given as suggestions for control. 


\section{Literature Cîted}

1. Barlett, Kenneth A. Introduction and colonization of two parasites of the pineapple mealybug. Jour. Agr. Univ. Puerto Rico 23 (2) : 67-72. 1939.

2. Carter, Walter. Studies of population of Pseudococcus brevipes (Ckl.) occurring on pineapple plants. Ecology 13: 296-304. 1932.

3. Border plantings as guard rows in pineapple mealybug control. Jour. Econ. Ent. 25: 1027-1030. 1932.

4. The pineapple mealybug, Pseudococcus brevipes, and wilt of pineapples. Phytopath 23: 207-242. 1933.

5. Fife, Courtney L. Insects and mite found on cotton in Puerto. Rico, with notes on their economic importance and natural enemies. Puerto Rico Exp. Sta. U. S. D. A., Bul. 39, 9 p. 1939.

6. Illingworth, J. E. Preliminary report on evidence that mealybugs are an important factor in pineapple wilt. Jour. Econ. Ent. 24: 877-889. 1931.

7. Latta, Randall. The vapor-heat treatment as applied to the control of narcissus pests. Jour. Econ. Ent. 25: 1020-1026. 1932.

8. McBride, O. C. Effect of heat on the pineapple mealybug (Pseudococous brevipes). (Unpublished report). 1932.

9. Plank, H. K. Exploratory treatments to clean sugarcane seed pieces of stalk mealybugs. (Unpublished report). 1928.

10. Smith, M. R. The Ants of Puerto Rico. Jour. Agr. Univ. Puerto Rico 20: 819-875. 1936.

11. Wolcott, George N. "Insectae Borinquenses". A revised annotated check-list of the insects of Puerto Rico, with a hostplant index by José I. Otero. Jour. Agr. Univ. Puerto Rico 20 (1) : 123. 1936. 